\title{
Study of the Farm Activities Done by Rural Women and Impact of Drudgery on Women and Children
}

\author{
Sakshi Mishra ${ }^{1 *}$, Ragini Dubey ${ }^{2}$, Pooja Arya ${ }^{1}$ and Dipti ${ }^{3}$ \\ ${ }^{1}$ Maharana Pratap University of Agriculture and Technology, Udaipur, 313001, India \\ ${ }^{2}$ Ragini Dubey, Ph. D, Punjab Agricultural University, Ludhiana, India \\ ${ }^{3}$ Gobind Ballabh Pant University of Agriculture and Technology, Pantnagar, India
}

*Corresponding author

\section{A B S T R A C T}

\section{Keywords \\ Farm practices, \\ Domestic \\ management, \\ Women \\ empowerment, \\ Allied activities, \\ Drudgery}

Article Info

Accepted:

12 September 2020

Available Online:

10 October 2020
Most of the population in India is dependent on agriculture and it is the largest employment sector in the nation. Women play a vital role in agriculture as well as in domestic management in allied activities. Women are considered as the backbone of agriculture in try and hilly areas of rural region. The present study was carried out in two districts of Uttarakhand State. A sample size of 120 respondents was taken for descriptive data using purposive and random sampling. Interview the descriptive data was collected with the help of interview schedule method to study the practices adopted and impact of drudgery on women and children.

\section{Introduction}

Women are identified as the main pile of development. Women plays an important role in family resource management by running multiple rows by taking care of the house, perform household and form related activities like transplanting, weed management, harvesting salting winnowing and list of activities accept land preparation and transporting. Women contribute in the survival of their family and are solely responsible for any money management in low income group. Empowerment of women is a process of gaining self-confident former control over resources and control over existing social attitude and perception top it is essential to achieve gender equality equal rights in the society for better quality of life. Women face many constraints in both areas inside house or outside the house. In rural and hill areas agriculture women workers are unorganized and dispersed. In these areas most of the women are illiterate and have low 
level of education. They also have the poor bargaining power. Sometimes due to the seasonal work and in off season they generally have to shift to alternative work for employment. Many of women ended up as bonded labourers because of these situations. Drudgery of women can be reduced by improved or drudgery reducing gender friendly tools. These tools are scientifically or ergonomically designed for farm women. It bridges the communication between the users and design engineers. These tools reduce drudgery, improve efficiency, reduce ill health, reduce stress or fatigue and increase productivity and increase the satisfaction of the women and their health.

\section{Materials and Methods}

A descriptive design was chosen to assess the farm activities done by rural women and impact of drudgery on women and children with the help of interview schedule. A sample size of 120 respondent was taken for descriptive data using purposive and random sampling the data was collected personally by using the interview schedule method. A visit was made to the villages of Tarai and hilly areas of Uttarakhand.

\section{Results and Discussion}

Farm women perform many farm activities like tillage and seed preparation about 68 percent, followed by sowing and planting, weeding and intercultural operations, harvesting, threshing and grading 69.3 percent, 43.3 percent 18.7 percent respectively (Bhushan et al., 2016) (Fig. 1 and 2).

\section{Tillage and seedbed preparation}

Table 1 shows that 12.5 percent female respondents performed this activity in total, 6.67 percent respondents performed this activity in tarai region and 18.34 percent female respondents performed this activity in hilly region. Tillage and seedbed activity were mainly performed by the male members. Hilly region respondents performed this activity more than tarai region respondents.

Sowing and planting: 78.34 percent female respondents performed this activity. In tarai region, 63.34 percent female and in hill region 93.33 percent female respondents performed this activity. Sowing activity was generally performed manually.

\section{Weeding and intercultural operations}

Weeding and intercultural activity was mostly performed by the female respondents. It is clear from the table 1 that 90.84 percent female respondents performed this activity. In the tarai region, 86.67 percent female and in hill region 95 percent female respondents performed this activity. This activity was also done by hand and using traditional khurpi for weeding activity.

\section{Harvesting, threshing and grading}

Table 1 reveals that majority of the female performed this activity. It was about 84.17 percent female respondents performed these activities. In tarai region, 76.67 percent female respondents and in hill region, 91.67 percent female respondents performed this activity. Harvesting was mainly done by use of sickle; threshing is done by traditional method by beating on wooden plank.

\section{Livestock management}

This activity is mostly performed by female. Table 1 shows that 93.34 percent female respondents performed this activity. In tarai region, 90 percent female respondents and in hill region 96.67 percent female respondents performed this activity. Male did not have contribution in livestock management. 


\section{Impact of drudgery on women}

Table 2.1 shows that about 93.34 percent respondents had heavy physical strain in their body. In the tarai region, 88.34 percent and in hill region 98.34 percent respondents were affected by heavy physical strain. Three fourth of the total respondents had fatigue in their routine due to overburdened with work at home. In tarai region, 75 percent and in hill region 76.65 percent respondents faced the fatigue problem. Thirty seven percent respondents were malnourished. In tarai region, 30 percent and in hill region, 45 percent respondents faced the malnourishment problem. Ninety three percent had physical stress due to work overload. In the tarai region, 88.34 percent and in hill area 98.34 percent respondents affected by physical stress due to work overload in home, farm and allied activities.

Table.1 Practices being followed by farm women

\begin{tabular}{|c|c|c|c|}
\hline \multirow[t]{2}{*}{ Practices } & \multicolumn{3}{|c|}{ Frequency } \\
\hline & Tarai region & Hill region & Total \\
\hline \multicolumn{4}{|l|}{ Performed Farm operation } \\
\hline Tillage and seedbed preparation & $\begin{array}{c}4 \\
(6.67)\end{array}$ & $\begin{array}{c}11 \\
(18.34)\end{array}$ & $\begin{array}{c}15 \\
(12.5)\end{array}$ \\
\hline Sowing and planting & $\begin{array}{c}38 \\
(63.34)\end{array}$ & $\begin{array}{c}56 \\
(93.33)\end{array}$ & $\begin{array}{c}94 \\
(78.34)\end{array}$ \\
\hline Weeding and intercultural operations & $\begin{array}{c}52 \\
(86.67)\end{array}$ & $\begin{array}{c}57 \\
(95)\end{array}$ & $\begin{array}{c}109 \\
(90.84)\end{array}$ \\
\hline Harvesting/threshing/grading & $\begin{array}{c}46 \\
(76.67)\end{array}$ & $\begin{array}{c}55 \\
(91.67)\end{array}$ & $\begin{array}{c}101 \\
(84.17)\end{array}$ \\
\hline Livestock management & $\begin{array}{c}54 \\
(90)\end{array}$ & $\begin{array}{c}58 \\
(96.67)\end{array}$ & $\begin{array}{c}112 \\
(93.34)\end{array}$ \\
\hline \multicolumn{4}{|l|}{ Any tools/machinery at farm } \\
\hline YES & $\begin{array}{c}60 \\
(100)\end{array}$ & $\begin{array}{c}60 \\
(100)\end{array}$ & $\begin{array}{c}120 \\
(100)\end{array}$ \\
\hline \multicolumn{4}{|c|}{ Any problems in using these tools (traditional tools) } \\
\hline YES & $\begin{array}{c}51 \\
(85)\end{array}$ & $\begin{array}{c}55 \\
(91.67)\end{array}$ & $\begin{array}{c}106 \\
(88.34)\end{array}$ \\
\hline NO & $\begin{array}{c}9 \\
(15)\end{array}$ & $\begin{array}{c}5 \\
(8.34)\end{array}$ & $\begin{array}{c}14 \\
(11.67)\end{array}$ \\
\hline \multicolumn{4}{|l|}{ Major problems } \\
\hline Non-availability of tools & $\begin{array}{l}48 \\
(80)\end{array}$ & $\begin{array}{c}51 \\
(85)\end{array}$ & $\begin{array}{c}99 \\
(82.5)\end{array}$ \\
\hline $\begin{array}{l}\text { Availability of cash/credit related } \\
\text { problems }\end{array}$ & $\begin{array}{c}46 \\
(76.67)\end{array}$ & $\begin{array}{c}49 \\
(81.67)\end{array}$ & $\begin{array}{c}95 \\
(79.17)\end{array}$ \\
\hline Skill & $\begin{array}{c}22 \\
(36.67)\end{array}$ & $\begin{array}{c}26 \\
(43.34)\end{array}$ & $\begin{array}{c}48 \\
(40)\end{array}$ \\
\hline $\begin{array}{l}\text { Non-availability of information about } \\
\text { tools }\end{array}$ & $\begin{array}{c}45 \\
(75)\end{array}$ & $\begin{array}{c}52 \\
(86.67)\end{array}$ & $\begin{array}{c}97 \\
(80.84)\end{array}$ \\
\hline
\end{tabular}


Table.2.1 Impact of drudgery on women

\begin{tabular}{|l|c|c|c|}
\hline \multicolumn{1}{|c|}{ Factor } & \multicolumn{3}{|c|}{ Frequency } \\
\hline & Tarai region & Hill region & Total \\
\hline Heavy physical strain & 53 & 59 & 112 \\
& $(88.34)$ & $(98.34)$ & 91 \\
\hline Overwork fatigue & 45 & 46 & $(75.84)$ \\
\hline Malnourishment & $(75)$ & $(76.65)$ & 45 \\
\hline Physical stress due to work overload & 18 & 27 & $(37.5)$ \\
\hline Mental stress due to work overload & $(30)$ & $(45)$ & 112 \\
\hline High incidence of miscarriage & 53 & 59 & $(93.34)$ \\
\hline Disease prone & $(88.34)$ & $(98.34)$ & 95 \\
& $(78.34)$ & 48 & $(79.17)$ \\
\hline Fluctuating lactation ability & 6 & $(80)$ & 15 \\
& $(10)$ & 9 & $(12.5)$ \\
\hline
\end{tabular}

Table.2.2 Impact of drudgery on child

\begin{tabular}{|l|c|c|c|}
\hline \multicolumn{1}{|c|}{ Factors } & \multicolumn{3}{|c|}{ Frequency } \\
\hline & Tarai region & Hill region & Total \\
\hline Deprivation of mother's attention & 48 & 51 & 99 \\
& $(80)$ & $(85)$ & $(82.5)$ \\
\hline Low birth weight & 32 & 38 & 70 \\
& $(53.34)$ & $(63.34)$ & $(58.34)$ \\
\hline High mortality rate & 6 & 9 & 15 \\
& $(10)$ & $(15)$ & $(12.5)$ \\
\hline Reduced breast feeding & 21 & 32 & 53 \\
& $(35)$ & $(53.34)$ & $(44.16)$ \\
\hline Neglected child & 46 & 48 & 94 \\
& $(76.67)$ & $(80)$ & $(78.34)$ \\
\hline
\end{tabular}

Fig.1 Distribution according to impact of drudgery on women

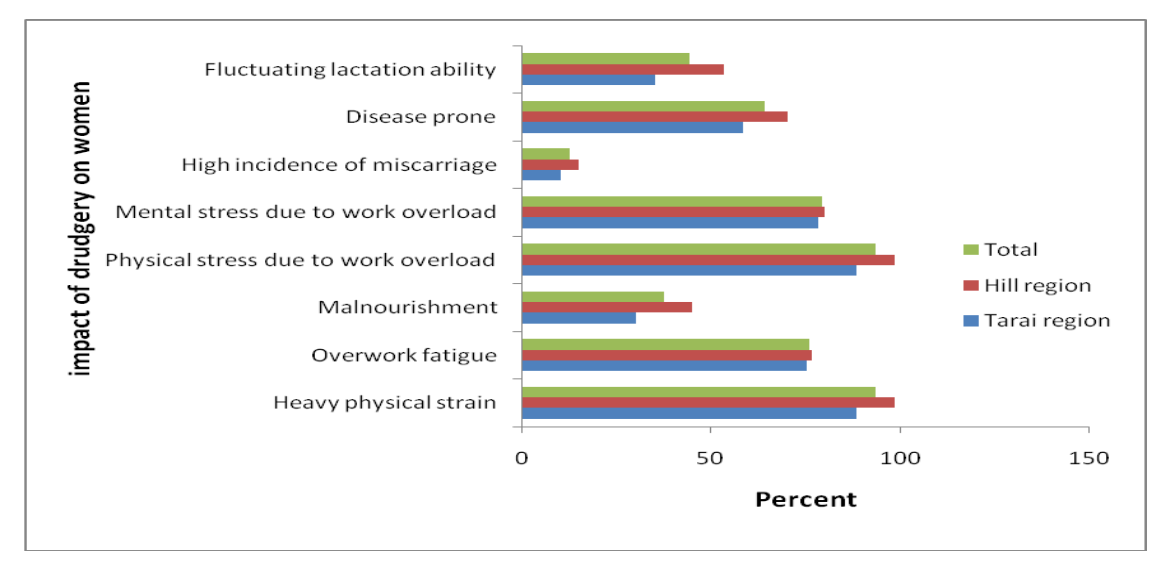


Fig.2 Distribution according to impact of drudgery on child

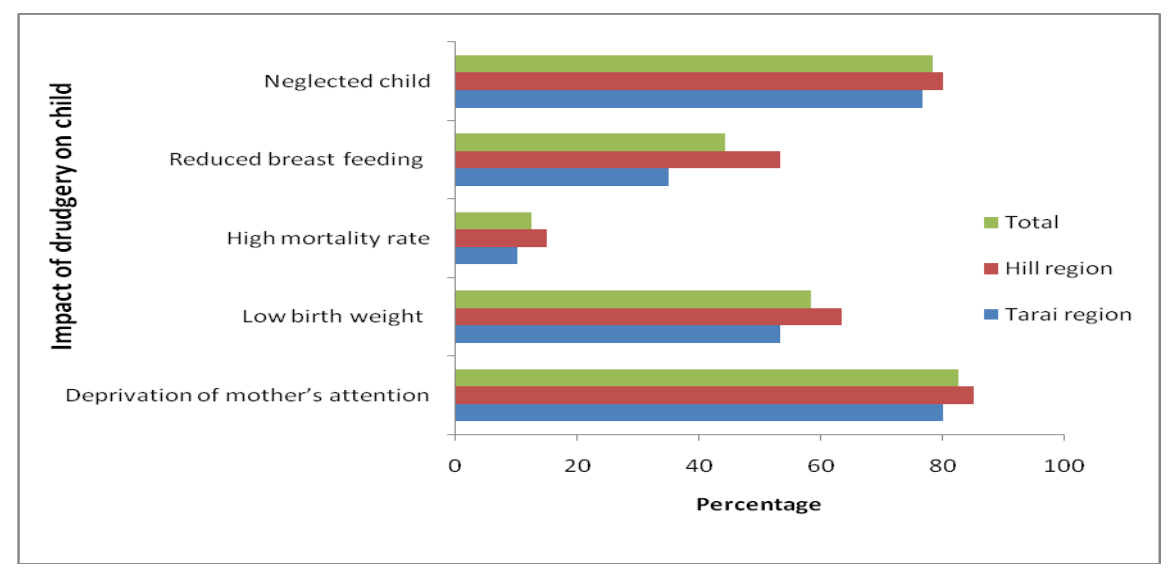

Seventy nine percent had mental stress due to work. In the tarai region, 78.34 percent and in hill area 80 percent respondents was affected by mental stress due to work. The drudgery had impact on 12.5 percent respondent's high incidence of miscarriage. In tarai region, 10 percent and in hill region, 15 percent respondents had this problem.

Overall, around sixty four percent respondents had the problem of disease prone. In tarai region, 58.34 percent and in hill region 70 percent respondents affected by disease prone especially skin related problem. Forty four percent respondents had the problem of fluctuating lactation ability due to drudgery. In tarai region, 35 percent and in hill region 53.34 percent respondents were affected by fluctuating lactation ability problem.

\section{Impact of drudgery on child}

Table 2.2 justifies the impact of drudgery on children. 82.5 percent respondents feel that children are deprived of mother's attention. Most respondents feel that they did not give time to their children. Eighty percent respondents in tarai and 85 percent respondent in hills feel that children were deprived of mother's attention.
More than half of the total respondents feel that their child had low birth weight affecting their growth. In tarai region, 53.34 percent and in hill region 63.34 percent respondent's children faced this problem. About twelve percent respondents faced the problem that due to drudgery their child had high rate of mortality. In the context of tarai region it was 10 percent and in hill region it was observed to be 15 percent.

Due to drudgery about 44.16 percent respondents had the feeling that their breast feeding reduced due to drudgery. In tarai region, 35 percent and in hill region, 53.34 percent respondents faced this problem. Seventy eight percent respondents felt that they did not give time to their child. In tarai region, 76.67 percent and in hill region, 80 percent respondents were of the opinion that their children are neglected due to workload.

In conclusion, the women constitute about 49 $\%$ of the population of the world. Women place multiple roles and responsibilities in the society and identified as the main pillar of development and progress for any country. Empowerment of women is a process of gaining self-confident, control over resources and control over existing social attitude and perception. It is essential to achieve gender equality, equal rights in the society for better 
quality of life. Empowerment process improves women skills or their access to production resources. It helps to maintain the quality, dignity and work of women in the community. It is only achieved when women condition and position is improved by enlarging social, economic and political freedom and choice. Drudgery is mainly result of the repetitive task, fatigue, physical stress, mental strain or hardship during activity experienced by the people. Generally Indian women feel more work for long time without rest and perform many roles in society and family. This drudgery or fatigue result in feeling tired, sleepiness, physical or mental stress, exhaustion and pain in body parts. So, it can be said that all the farm women suffer from the drudgery while performing various activities.

\section{References}

Borah, S. 2015. Physiological workload of hill farm women of Meghalaya, India involved in firewood collection. 6th
International Conference on Applied Human Factors and Ergonomics (AHFE) and the Affiliated Conferences, AHFE. Procedia Manufacturing 3: $4984-4990$.

Goswami, C. 2013. Female agricultural workers in Assam: a case study of Darrang district. International journal of scientific and research publications, 3(2).

Kumar, B.T.P.; Gowda, G. V. and Khandekar, N. 2011. Time utilization pattern and drudgery of horticultural farmers. International Journal of Engineering and Management Sciences, 2(2): 93 96.

Matpathi, R. 2015. Virtual prototype modelling and analysis of low-cost hand operated maize desheller. Indian J. Sci. Res, 11(1): 127-132.

Meeker, B.J.; Carruth, A. and Holland, C.B. 2002. Health hazards and preventive measures of farm women. Emerging issues. AAOHN Journal, 50(7): 307-1.

\section{How to cite this article:}

Sakshi Mishra, Ragini Dubey, Pooja Arya and Dipti. 2020. Study of the Farm Activities Done by Rural Women and Impact of Drudgery on Women and Children. Int.J.Curr.Microbiol.App.Sci. 9(10): 1289-1294. doi: https://doi.org/10.20546/ijcmas.2020.910.155 